\title{
The Role of Clay Mineral Composition on Silicified Coal Genesa Based on X-Ray Diffraction (XRD)
}

\author{
Basuki Rahmad1, Gerhana Prasetya', Sugeng1, Ediyanto1, \\ Muchamad Ocky Bayu Nugroho', Intan Permata Hatty ${ }^{1}$, Hariyadi ${ }^{2}$
}

${ }^{1}$ Geological Engineering Department, Faculty of Technology Mineral, Universitas Pembangunan Nasional “Veteran” Yogyakarta, Kota Yogyakarta, Indonesia ${ }^{2} \mathrm{PT}$. Adaro Indonesia, Jakarta, Indonesia

Email: basukirahmad@upnyk.ac.id

How to cite this paper: Rahmad, B., Prasetya, G., Sugeng, Ediyanto, Nugroho, M. O. B., Hatty, I. P., \& Hariyadi (2021). The Role of Clay Mineral Composition on Silicified Coal Genesa Based on X-Ray Diffraction (XRD). Journal of Geoscience and Environment Protection, 9, 192-208. https://doi.org/10.4236/gep.2021.97013

Received: June 6, 2021

Accepted: July 25, 2021

Published: July 28, 2021

\section{Copyright $\odot 2021$ by author(s) and} Scientific Research Publishing Inc. This work is licensed under the Creative Commons Attribution International License (CC BY 4.0).

http://creativecommons.org/licenses/by/4.0/

(c) (i) Open Access

\begin{abstract}
The interesting concern in this study is that in the same outcrop it was found that the first coal seam (coal seam-D) contains silicified coal and the second coal seam (coal seam-E) does not contain silicified coal and how to find out the cause. In general, the characteristics of silicified coal seam-D are in the form of lenses; the distribution extends from a few meters to several tens of meters with a thickness of three to five centimeters and some are in nodules. Environmental conditions are the main factor in the formation of silicified coal where the acidity level of coal bearing sediment seam-D which is between 3.4 (roof sediment) to 4.2 (floor sediment) is higher than coal bearing sediment seam-E which has a $\mathrm{pH}$ of 5.4. This condition indicates that the coal bearing sediment seam-D environment is more acidic than coal seam-E. The results of XRD analysis show that the seam-D containing silicified coal has a composition of $47.47 \%$ kaolinite, $21.27 \%$ illite, $23.73 \%$ smectite and $17.54 \%$ mixed layer, while the seam-E which does not contain silicified coal has a composition of kaolinite $35.78 \%$, illite $17.88 \%$, smectite $21.59 \%$ and mixed layer $24.76 \%$. Acidic environmental conditions $(\mathrm{pH})$ and silica enrichment in clay minerals (kaolinite) in the roof sediments during sedimentation, accelerated the process of deposition of colloidal silica in the wood structure of coal seams into silicified coal.
\end{abstract}

\section{Keywords}

Silicified Coal, Roof Sediment, pH, Kaolinite, Acid 


\section{Introduction}

The research is located in PIT “ $x$ ”, Tanjung area, Tabalong Regency, South Kalimantan which is geologically included in the Barito Basin. The stratigraphy of research area is composed of the Warukin Formation which was deposited during the Middle Miocene to the Late Miocene (Satyana et al., 1994). The Warukin Formation is a coal bearing formation in the Barito Basin. The coal in the research area consists of nine seams, namely seams A, B, C, D, E, F, G, H and I. The coal in the research location has the rank of lignite to sub-bituminous coal, which is low in sulfur content. The location of the research area is shown in Figure 1 .

Observations in the field of the nine seams show that in the four seams, namely seams C, D, H and I. There are boulders and inserts of silica minerals (silicified coal). Silicified coal is organic material in the body of dead plants replaced by minerals from the soil but still maintains its external form as silicified morphology. For a long time, the components in wood were replaced by silica compounds (Sigleo, 1978).

The distribution pattern of silicified coal which has unique characteristics is lenses in the form of lenses with a length of several meters to hundreds of meters and in the form of nodules that are present locally ranging from cobble to boulder sizes.

Genesa or the process of forming silicified coal according to (Sigleo, 1978) and occurs due to the leaching process of the roof sedimentary rocks which contain high silica.

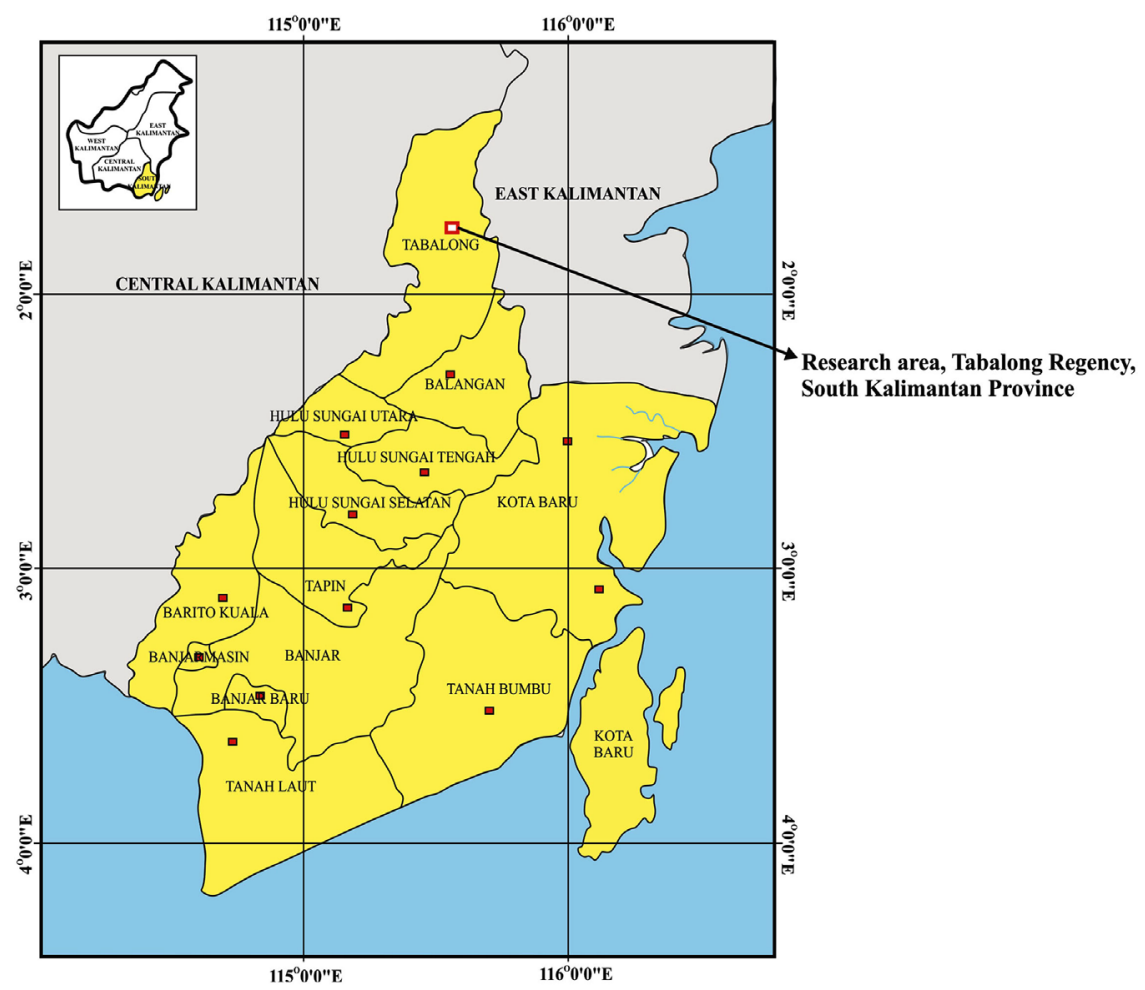

Figure 1. Research area, Tabalong Regency, South Kalimantan Province. 
Based on the explanation of silicified coal regarding the characteristics and genesis associated with the roof sedimentary rock, it is important to conduct research on the role of the roof sedimentary rock composition on the genesis of silicified coal. The roof sedimentary rock layer with carbonaceous claystone lithology must be carried out with an X-ray diffraction (XRD) clay oriented analysis to identify the clay mineral composition which influences the formation of silicified coal.

\section{Geological Setting}

Regionally the research area is included in the Barito Basin. The Barito Basin covers an area of $70,000 \mathrm{~km}^{2}$ in Southeast Kalimantan. This basin is located between two elements of the Mesozoic age (the Sunda Shelf in the west and the Meratus Mountains which is a tectonic melange route to the east) as shown in Figure 2.

Kalimantan Island is the largest island that is part of the Sunda Micro Plate. According to, the Southeast Asian plate is interpreted as a fragment of the Eurasian plate that subduct to the southeast as a result of the collision of the Indian continental crust with the Asian continental crust, which occurred approximately 40 - 50 million years ago. This fragment of the Eurasian plate became known as the Sunda micro plate which includes the Malay peninsula, Sumatra, Java, South Kalimantan and Central Kalimantan.

According to van Bemmelen (1949) the island of Kalimantan is divided into several physiographic zones as shown in Figure 3. The physiographic zones are:

1) The Schwaner Block which is considered part of the Sunda plain.

2) Paternoster Block, covering the present Paternoster courtyard which is located off the coast of Southeast Kalimantan and partly in the Kalimantan plain which is known as the Pasir sub basin.

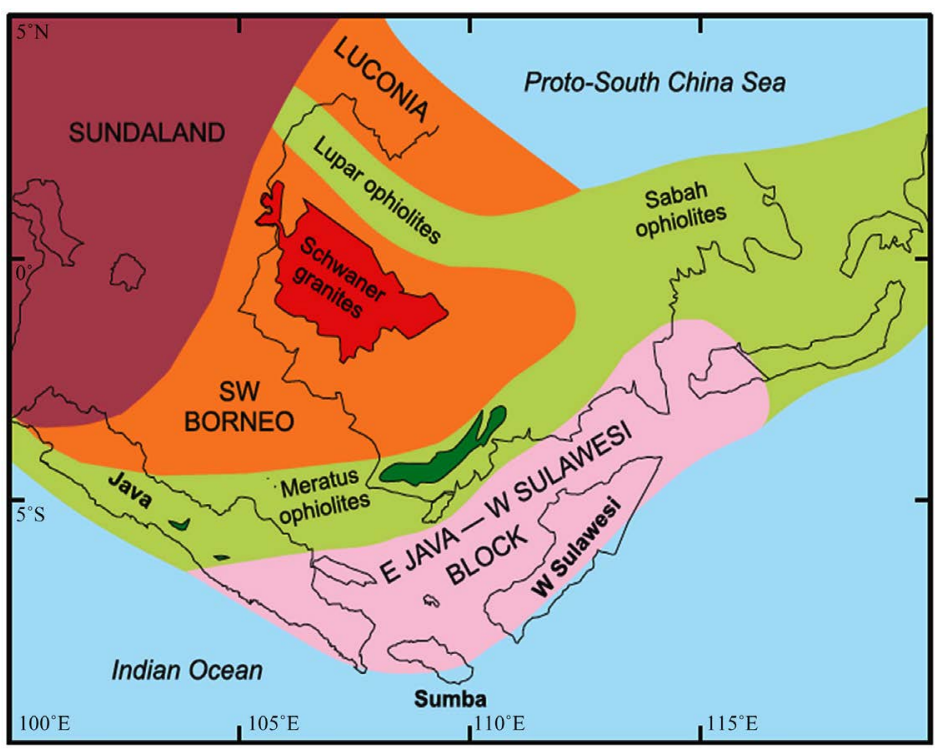

Figure 2. The tectonic history of the formation of the island of Borneo (Hall et al., 2002). 


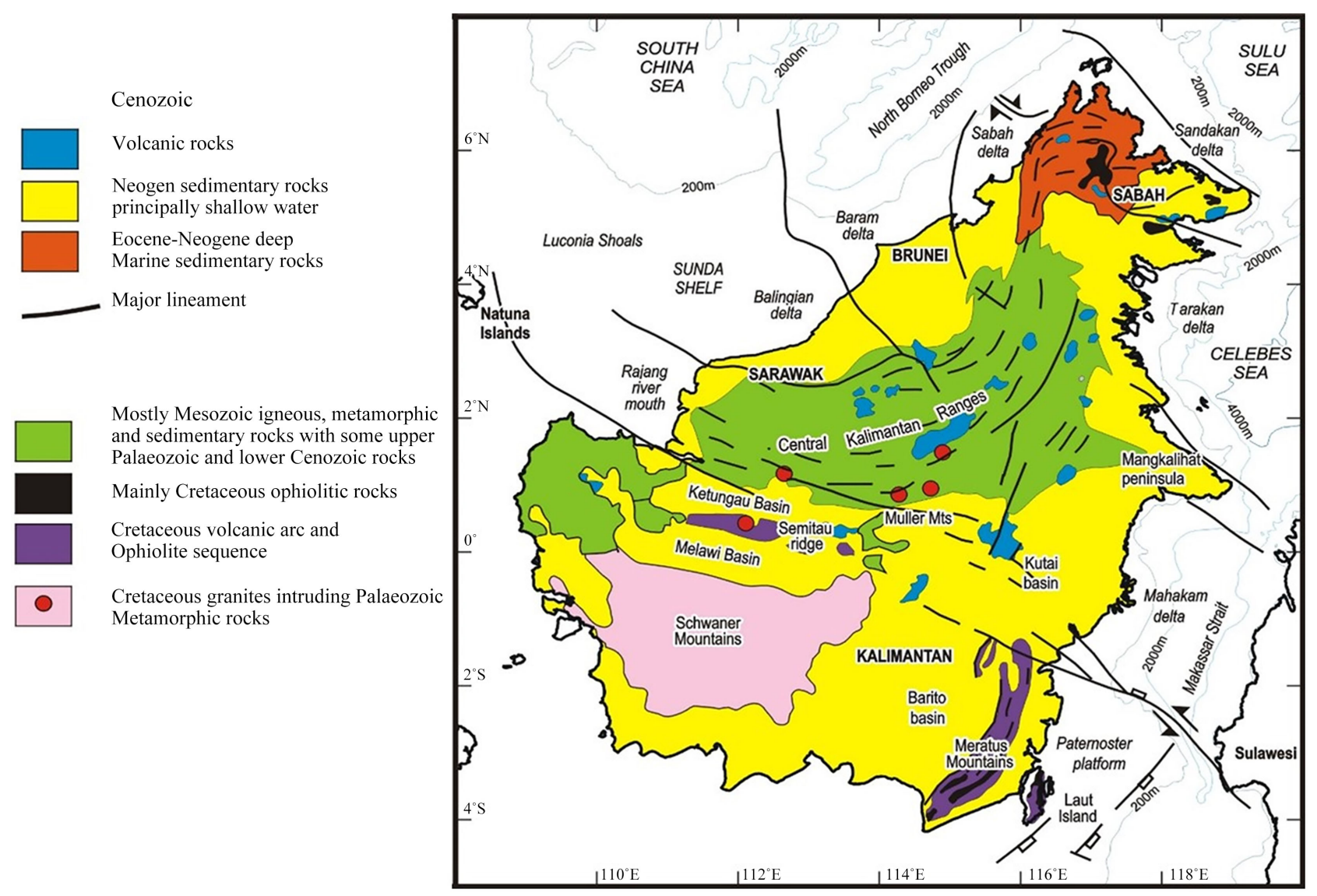

Figure 3. Physiography of Kalimantan Island (Hall et al., 2002).

3) Meratus Graben, located between the Schwaner and Paternoster blocks, this area is part of the Kutai basin.

4) Tinggi Kuching, is a source for deposition towards the Northwest and SouthEastern Borneo basin during the Neogene. These basins include:

a) The Tarakan Basin, which is located at the northernmost point of East Kalimantan.

b) To the north the basin is bordered by "Semporna High".

At the beginning of the Tertiary era, deformation occurred as a result of the tectonic oblique convergence in a northwest-southeast (NW-SE) direction. Then fractures formed and developed into accommodation space for alluvial fan sediment products and lacustrine which are members of the lower Tanjung Formation. In the early middle Eocene, as a final result of transgression, the rift or fracture developed into a fluviodeltaic and eventually a marine environment, which is entirely the result of transgression during the deposition process of the central Tanjung Formation. Between the early Oligocene and late Eocene, transgression occurred, resulting in sea inundation. As a result, shale marine is deposited from the upper Tanjung Formation.

After a regression occurred in the middle Oligocene, the Barito Basin experienced sagging, due to another transgression. The location of Barito Basin is shown in Figure 4. During the late Oligocene, the carbonate platform was depo- 
sited, a member of the Berai Formation. The carbonate sediment then undergoes deposition again during the early Miocene, when the deposition ends; the clastic sedimentary material undergoes deposition from the western part.

During the Miocene, there was a sea level drop until then the Schwaner Core and the Meratus Mountains underwent uplift. The clastic sedimentary material comes from the deposition process towards the east, and the progadation of sediment products from the delta which is a member of the Warukin Formation. In the late Miocene, the Meratus Mountains reappeared, followed by a subsidence resulting in a deposition of sediment, which is the Warukin Formation. The Meratus Mountains then underwent another uplift until the Pleistocene, and molasic-deltaic sedimentary rock products were deposited, a Dahor Formation during the Pliocene. The tectonic and deposition process continues today. The details of tectonostratigraphy of Barito Basin are shown in Figure 5.

The structural pattern that develops on the Kalimantan island is meratus (northeast-southwest). This pattern does not only occur in fault structures but also in the direction of the fold axis. The Tutupan Hills towards northeast-southwest with a length of about $20 \mathrm{~km}$ were formed due to the movement of two unidirectional faults. One of them is known as the dahai thrust fault, which extends to the west of the Tutupan hills.

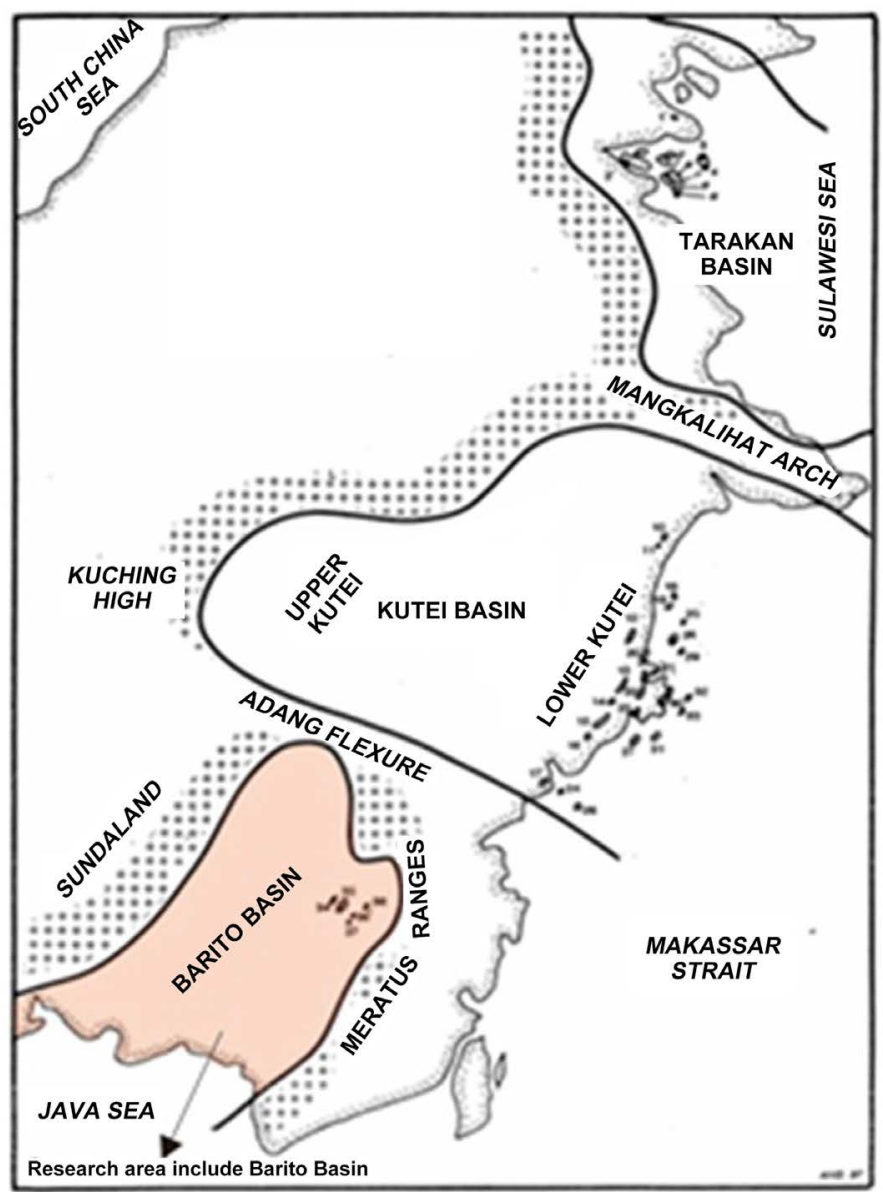

Figure 4. The location of Barito Basin (Satyana et al., 1994). 


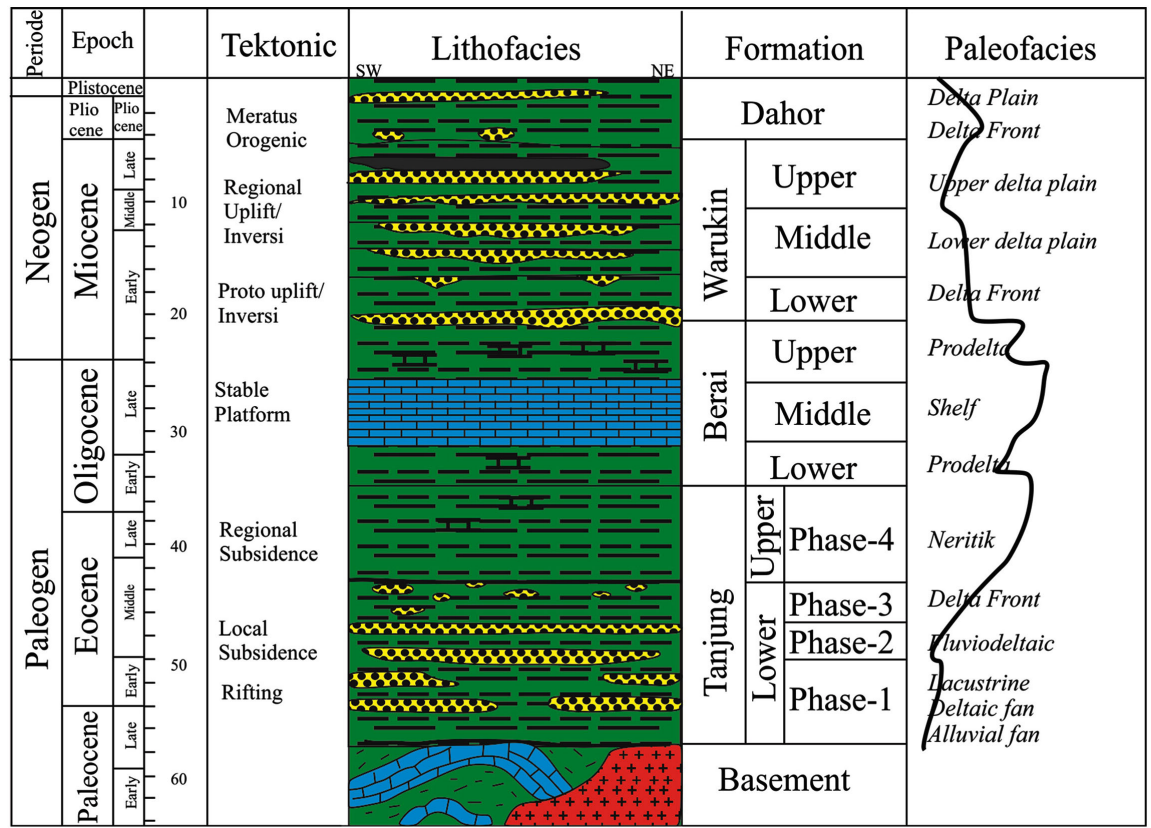

Figure 5. Tectonostratigraphy of Barito Basin (Satyana et al., 1994).

Another fault is called Tanah Abang-Bank Timur Thrust Fault which extends from the eastern foothills of the Tutupan Hills. The existence of this fault is known based on seismic data and oil well drilling. Another fault that is not connected to the Tutupan hills and to the northeast-southwest direction is found in the Wara area called the Maridu thrust fault. The faults that occur are generally in the same direction as the bedding so they do not interfere with the spread of coal.

The method for determining the lithology of the research area is measuring section analysis. Measuring section is a detailed description of lithology which is carried out by stretching the meter, walking through the side wall and doing a detailed description of the sedimentary rock layers in the study area so that it can determine the boundary of the rock unit and the sedimentation mechanism of the research location.

The stratigraphy and coal formations of research area are shown in Figure 6. The research location is composed of Warukin Claystone Unit and the Warukin Sandstone Unit. The Warukin Claystone Unit consists of carbonaceous claystone, shally coal, siderite claystone, coal (thickness 10 - 60 meters) with silicified coals and charcoal fragments. The sedimentary structures formed are massive, stratified, wavy bedding, wavy lamination, parallel lamination, and flaser. Seam-A, seam-B, seam-C, seam-D, seam-E, seam-F, and seam-G are seams contained in the Warukin Claystone Unit. The Warukin Sandstone Unit consists of carbonaceous claystone, shally coals, brown to gray quartz sandstone, sideritic sand-stone, coal (thickness 6 - 30 meters) with silicified coals and charcoal fragments. The sedimentary structures formed in the Warukin-sandstone unit are stratified, wavy bedding, wavy lamination, parallel lamination, cross bedding and flaser. Seam-H and seam-I are seams contained in Warukin-sandstone unit. The coal rank in the studied area is lignite-subbituminous with low sulphur. 


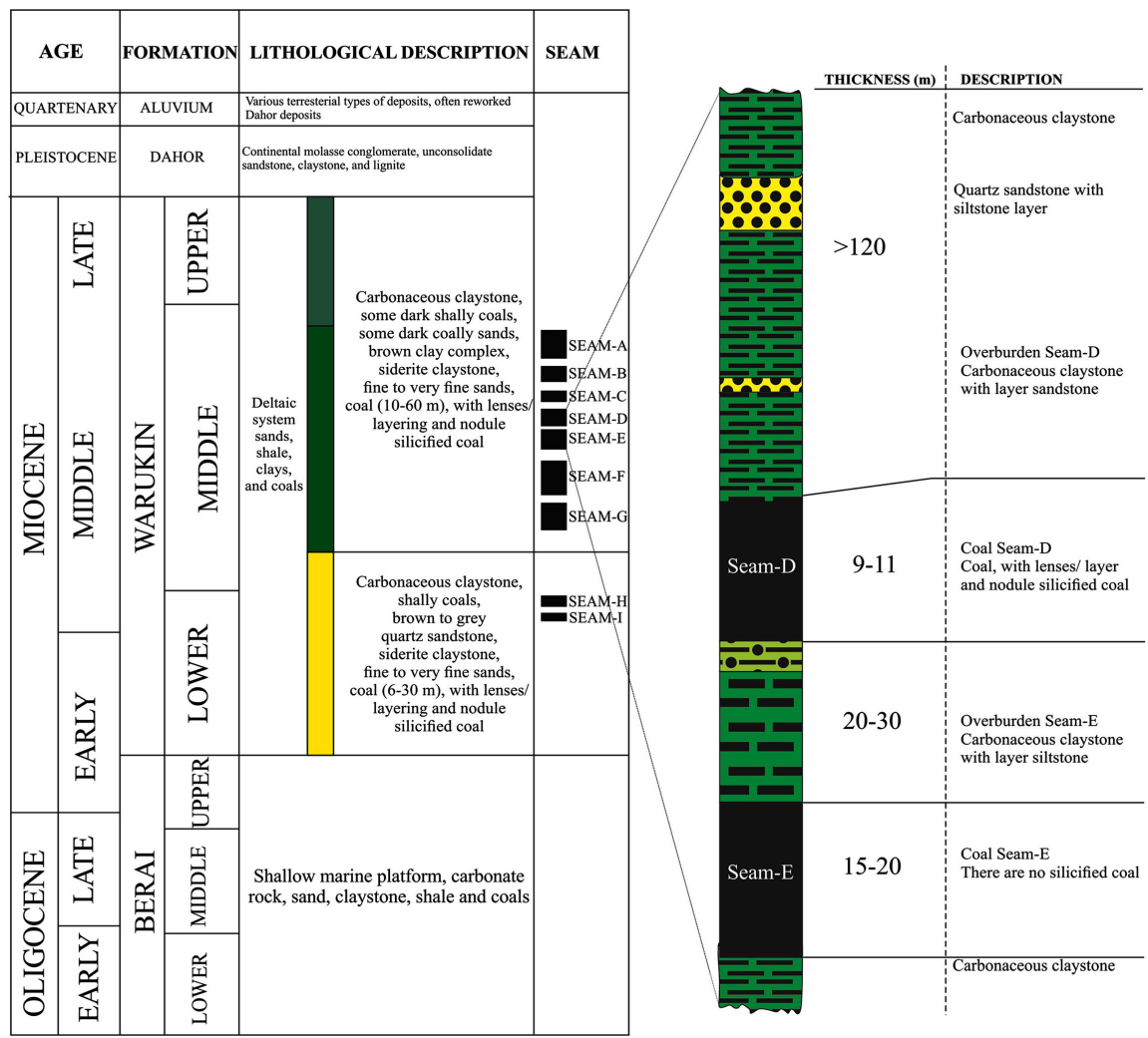

Figure 6. Stratigraphy and coal formations of research area.

\section{Sample and Methods}

This research conducts a coal mining in Tanjung area and its surroundings. The methods carried out in the field are coal observation, sampling and silicified coal profile correlation that assisted with the excavator unit. The excavator unit performs cleaning in the seam area so that the silicified coal in the seam-D is clearly observed. The main target of the coal seam is seam-D in Warukin Claystone Units.

Silicified coal and roof sediment are sampled to determine clay minerals composition which has an effect on the Genesa of silicified coal in seam-D. The correlation profile is carried out by ten meters (as shown in Figure 7), but if it is found that silicified coal has a nodule pattern of less than ten meters, the correlation profile is still carried out so that the silicified coal distribution pattern can be seen in the seam.

Studio analysis work includes:

1) Silicified coal correlation profile

The silicified coal correlation profile aims to determine the distribution and accumulation patterns of silicified coal in seam-D so that a 3 Dimension (3D) of silicified coal block model can be made. Correlation profile is done by doing a correlation profile along seam-D by ten meters but if silicified coal is found in nodule shape less than ten meters, it still needed to make correlation profile. The correlation profile is assisted by excavator unit, so it can determine the distribution pattern of silicified coal. 


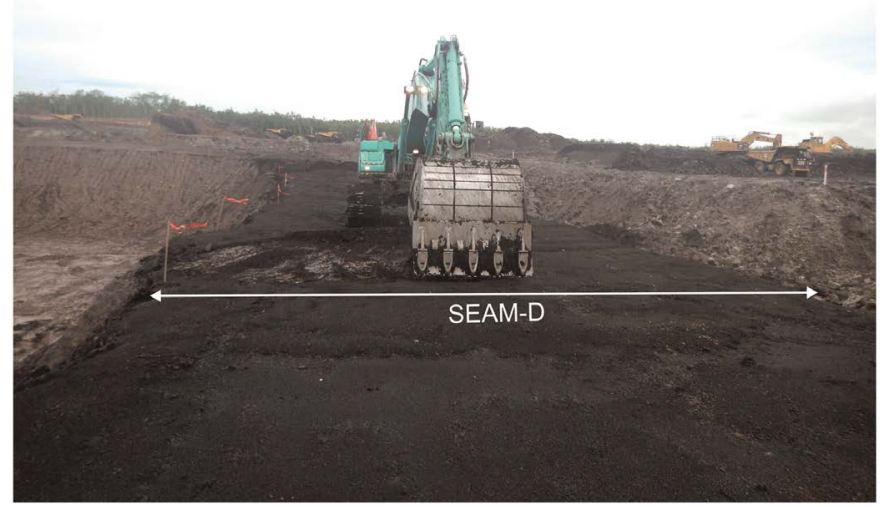

Figure 7. Correlation profile method in Seam-D assisted by units of excavators.

2) $3 \mathrm{D}$ block model of the silicified coal distribution pattern

The purpose of 3-dimensional block (3D) model of the silicified coal distribution pattern is to determine the distribution pattern of silicified coal of seam-D in a $3 \mathrm{D}$ framework.

Laboratory analysis work includes:

1) Acid level test $(\mathrm{PH})$

The acidity level test $(\mathrm{PH})$ aims to determine the effect of $\mathrm{PH}$ roof and floor sedimentary rocks on the formation process of silicified coal. The acidic level of acidity can accelerate the deposition of colloidal silica. The acidity test of the sedimentary rock is carried out in a laboratory at the mining company site.

2) X-ray diffraction (XRD) clay oriented of silicified coal

XRD clay oriented aims to determine the effect of clay mineral composition of upper sedimentary rock with the formation of silicified coal. XRD clay oriented is only identifies clay mineral composition of the roof sedimentary rock. XRD analysis is done for seam-D containing silicified coal and seam-E which did not contain silicified coal. Then the XRD result is compared with composition and percentage of clay minerals so that the composition and percentage of clay minerals that affected the formation of silicified coal could be identified.

\section{Result and Discussion}

The characteristics of silicified coal based on field data are divided into two forms, lenses with length of 12 meters to 215 meters with thickness of $3-5 \mathrm{~cm}$ (Figure 8) and nodules with size of $15-80 \mathrm{~cm}$ (cobbles-boulders) as shown in Figure 9. Two characteristics of these distribution pattern are indeed common in coal seams (Hidayatullah \& Jati, 2018).

The results of profile correlation data analysis in 3-Dimensional block of silicified coal distribution pattern shows in Figure 10 that silicified coal accumulation is at $0.38-4.76$ meters from the coal's floor, from $9-11$ meters of coal's thick or the silicified coal has accumulated on the floor to the middle seam-D. Figure 11 shows Silicified coal correlation profile of seam-D. 


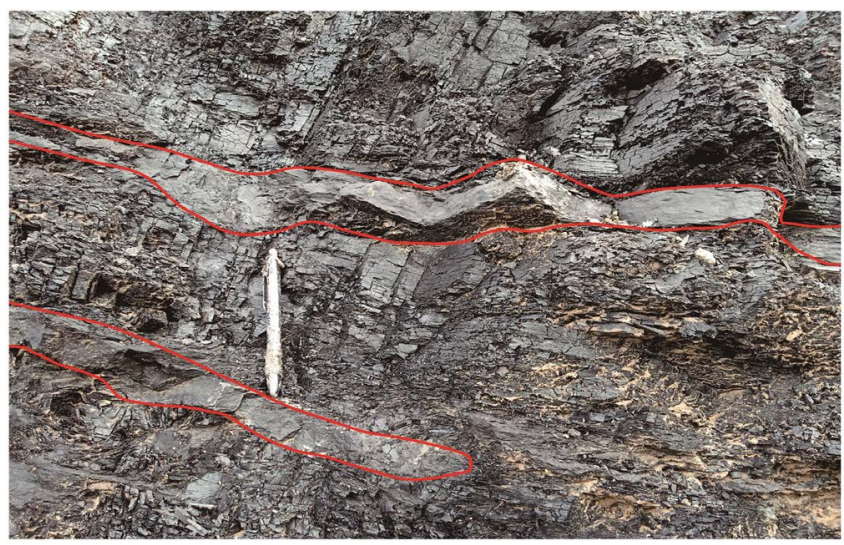

Figure 8. Lenses silicified coal on seam-D.

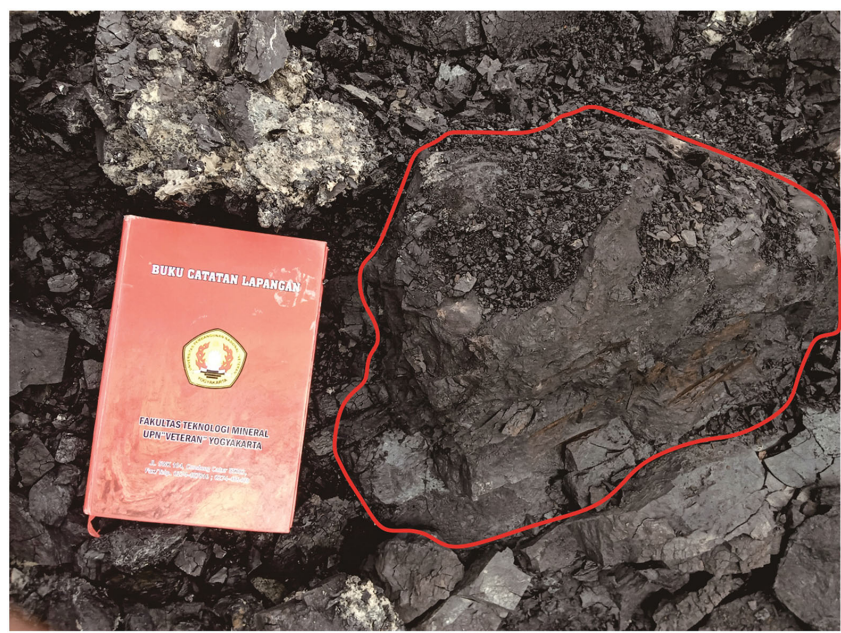

Figure 9. Nodule silicified coal on seam-D.

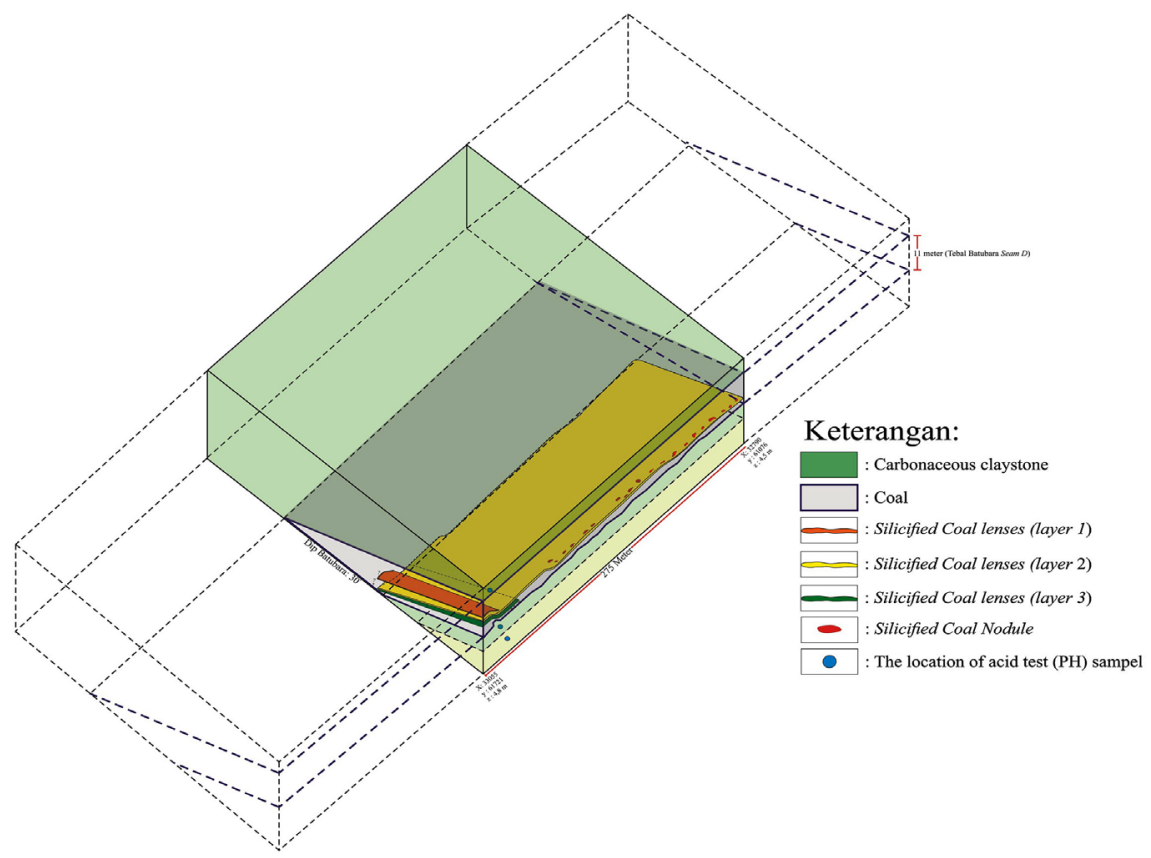

Figure 10. Blok 3-dimension of silicified coal seam-D. 


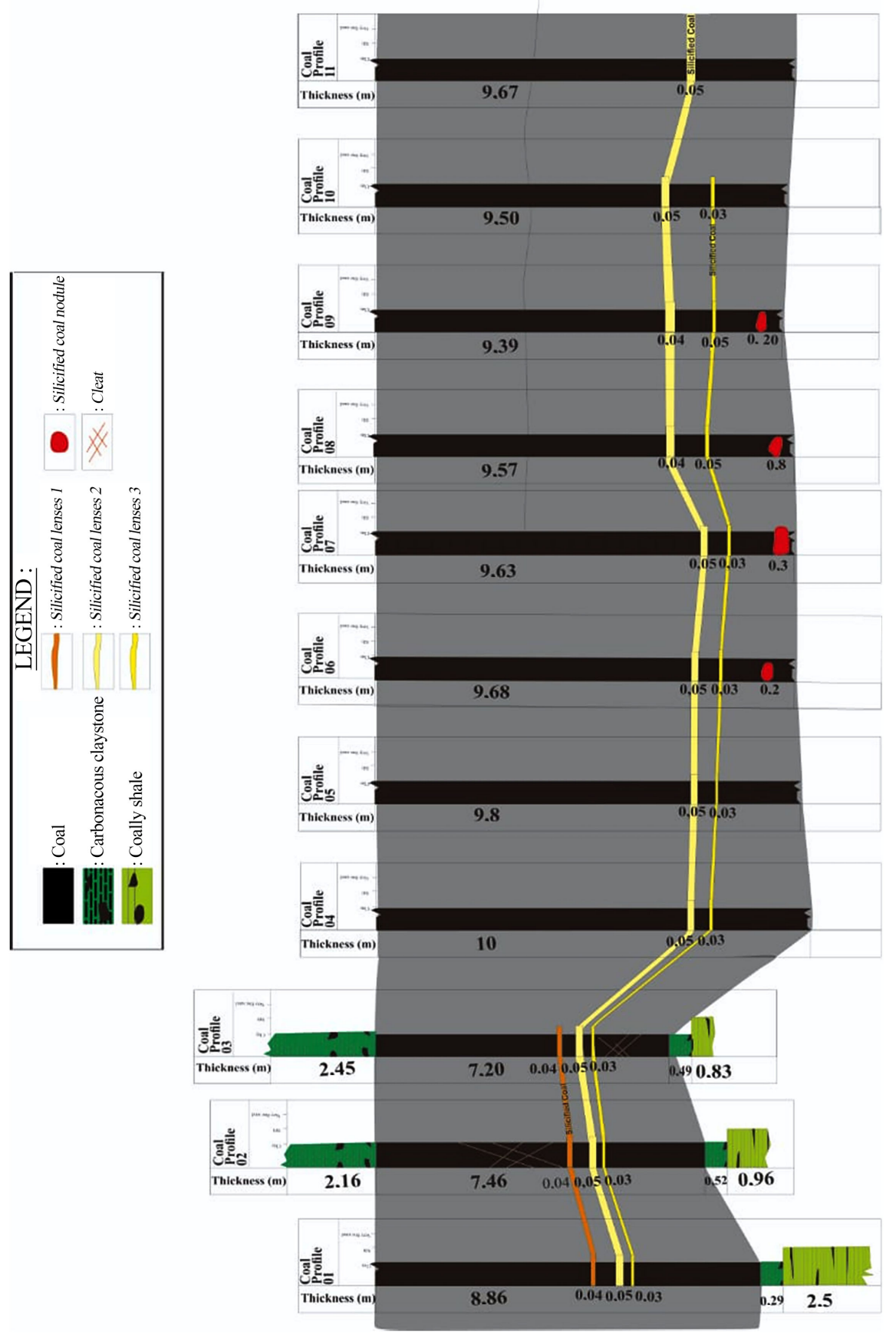

Figure 11. Silicified coal correlation profile of seam-D.

$\mathrm{PH}$ analysis of the floor and roof sedimentary rock layers aims to determine the relationship between the acidity of the roof and floor sedimentary rock layers to the effect of the emergence of silicified coal. The location of $\mathrm{pH}$ acidity test sampling on seam-D is shown in Figure 12 and Table 1 shows the results of the analysis of the $\mathrm{pH}$ acidity level of the sedimentary of seam-D and seam-E. Referring to Diessel, 1992 which explains the relationship between the acidity level of the depositional environment and the activity of anaerobic bacteria, 
states that anaerobic bacteria can thrive in environments with a neutral $\mathrm{PH}$ or close to PH 7, the acidity level causes anaerobic bacteria to not develop properly. so that the decay process does not take place optimally, so many wooden structures are found. Based on Sigleo (1978) silica permineralization occurs in an acidic swamp.

Charcoal is formed because the vegetation that forms coal has burnt due to geological cycles such as forest fires or lightning strikes so that the vegetation cannot be decomposed by anerobic bacteria.

In the formation of silicified coal, charcoal can become a gap or entry way for colloidal silica to enter the coal seam so that it can deposit silica minerals in the coal both in a continuous pattern of lenses ranging from several meters to several tens of meters and in the form of locally dispersed nodules. For example, fragmen charcoal in seam-D is shown in Figure 13.

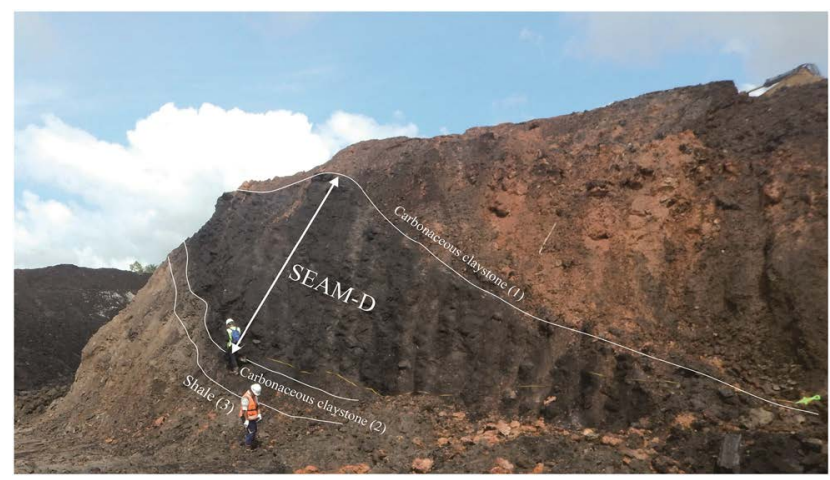

Figure 12. Location of $\mathrm{pH}$ acidity test sampling on seam-D.

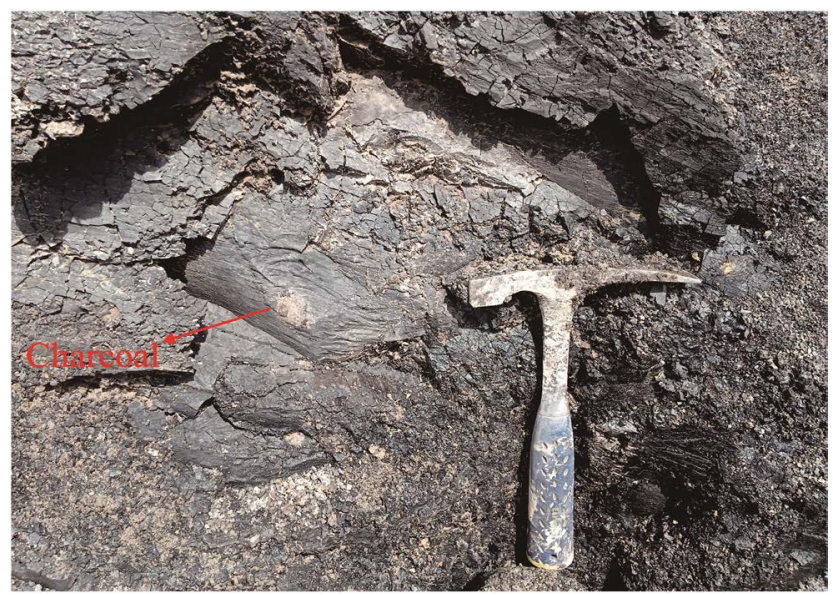

Figure 13. Fragmen charcoal in seam-D.

Table 1. The results of the analysis of the $\mathrm{pH}$ acidity level of the sedimentary rock roof and floor seam-D.

\begin{tabular}{cccccc}
\hline \multicolumn{5}{c}{ Acidity Test (PH) } \\
\hline No & Sample & Litology & Sediment (Roof/Floor) & PH & Result \\
\hline 1 & Layer 1/floor seam-D & Carbonaceous claystone & Roof & 4.2 & Acid \\
2 & Layer 2/roof seam-D & Carbonaceous claystone & Roof & 3.4 & Acid \\
3 & Layer 3/roof seam-E & Shale & Floor & 5.4 & Acid \\
\hline
\end{tabular}


According to Sigleo (1978), Genesa or the formation of silicified coal occurs due to the leaching process or dissolution of sedimentary roof rock with high primary (syngenetic) silica content so that silica minerals are dissolved by rainwater or formation water so it is necessary. It is important to know that clay minerals are the cause and source of the silica which is responsible for the formation of silicified coal. Clay minerals that are formed are minerals from secondary process, that is, minerals are not formed directly. So it is important to do an x-ray diffraction or XRD analysis to analyze the percentage amount and type of mineral composition of carbonaceous claystone as a coal roof sediment so that it can compare the mineral composition of carbonan claystone as a roof sediment seam-D which contains silicified coal with roof sediment seam "E" which does not contain silicified coal. The details of this X-ray diffraction (XRD) analysis are shown in Figure 14.

1) Roof sediment seam-D is a layer of research coal seam, coal containing silicifiedcoal, lithology of carbonic claystone from the results of XRD analysis it is written that the composition clay minerals of the carbonaceous claystone is kaolinite (47.47\%), illite (21.27\%), smectite (13.73\%) and mixed layer (17.54\%). Mixed layer is a mixture of illite and smectite clay minerals which have no meaning. From the data that shown in Table 2, kaolinite clay mineral is the dominant mineral, reaching $(47.47 \%)$ or almost half of the clay mineral composition of the seam-D roof sediment. sigleo (1978) explained that the chemical reaction results of changes in montmorillonite clay minerals with water so that they become kaolinite clay minerals and release silica compounds.

Sigleo (1978) also wrote a chemical reaction equation:

$$
\underset{\text { Montmorilonite }}{\mathrm{Al}_{2} \mathrm{Si}_{4} \mathrm{O}_{10}(\mathrm{OH})_{2}}+\underset{\text { Kaolinite }}{\mathrm{H}_{2} \mathrm{O}} \rightleftharpoons \underset{\text { Silika }}{\mathrm{Al}_{2} \mathrm{Si}_{2} \mathrm{O}_{5}(\mathrm{OH})_{4}}+\underset{\mathrm{SiO}_{2}}{2}
$$

The process of changing the chemical reaction produces silica compounds that dissolve with water. Next, fill the wood cellulose fibrils, and then they become silicified coal. Mencl and Sakala (2009) also explained that the coal bearing strata from the silicified wood layer in the Intra Sudetic Basin (ISB) region of the Czech Republic also consist of quartz and kaolinite clay minerals. Illite clay minerals also give a role in the formation of silicified coal, but because it is stable, it cannot significantly dissolve silica elements.

Table 2. Result of X-Ray Diffraction (XRD) analysis clay mineral composition sedimentary roof rock.

\begin{tabular}{|c|c|c|c|c|c|c|c|c|}
\hline \multicolumn{9}{|c|}{ Clay Mineral Composition Roof Sediment } \\
\hline \multirow{2}{*}{ No } & \multirow{2}{*}{ Sample } & \multirow{2}{*}{ Litology } & \multirow{2}{*}{$\begin{array}{l}\text { Containing } \\
\text { Silicified } \\
\text { Coal }\end{array}$} & \multirow{2}{*}{$\begin{array}{c}\text { Kaolinite } \\
(\%)\end{array}$} & \multirow{2}{*}{$\begin{array}{c}\text { Illite } \\
(\%)\end{array}$} & \multirow{2}{*}{$\begin{array}{c}\text { Smectite } \\
(\%)\end{array}$} & \multirow{2}{*}{$\frac{\text { Mixed Layer (\%) }}{\text { I/S R1 (Nat) - Irregular }}$} & \multirow{2}{*}{$\begin{array}{c}\text { Total } \\
(\%)\end{array}$} \\
\hline & & & & & & & & \\
\hline 1 & Roof Sediment Seam-D & Carbonaceous Claystone & Yes & 47.47 & 21.27 & 13.73 & 17.54 & 100.00 \\
\hline 2 & Roof Sediment Seam-E & Carbonaceous Claystone & No & 35.78 & 17.88 & 21.59 & 24.76 & 100.00 \\
\hline
\end{tabular}




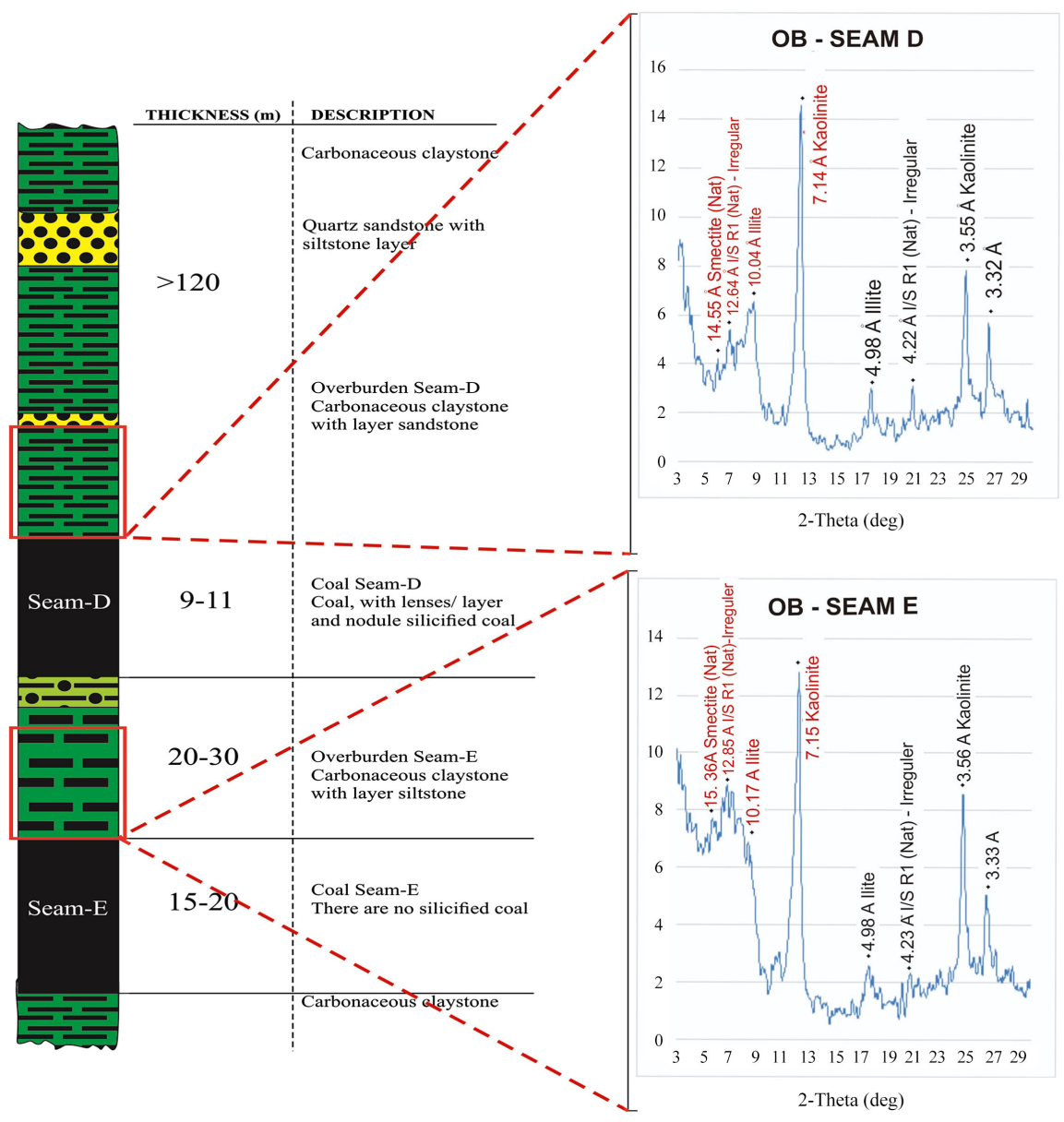

Figure 14. Location of X-ray diffraction(XRD) analysis of clay mineral composition roof sedimentary roof rock.

2) Roof sediment seam-E is coal seam that does not contain silicified coal with lithology of carbonaceous claystone from the XRD analysis results that the composition is kaolinite (35.78\%), illite (17.88\%), smectite (21.59\%) and mixed layer $(24.76 \%)$ or clay mineral mixture of illite and smectite clay minerals which have a meaningless structure. The striking difference between coal seam containing silicified coal and coal seam that does not contain silicified coal is the amount of kaolinite clay mineral. It was explained that the chemical reaction of montmorillonite clay mineral with water becomes kaolinite clay mineral and releases silica compounds, this means that in coal Seam-E it is still not completely free by silicified coal, it still has the potential to form silicified coal based on the presence of kaolinite (35.78\%) and illite (17.88\%).

The figure of carbonaceous claystone as roof sedimentary rock seam-D is shown in Figure 15, meanwhile the carbonaceous claystone as roof sediment of seam-E is shown in Figure 16.

Small gaps in the preserved cellulose fibrils open a way for the deposition of colloidal silica to fill the spaces of wood cells (Sigleo, 1978). In addition, gaps for the entry of silica material are also possible in a way that is based on (Stach, 1982) 


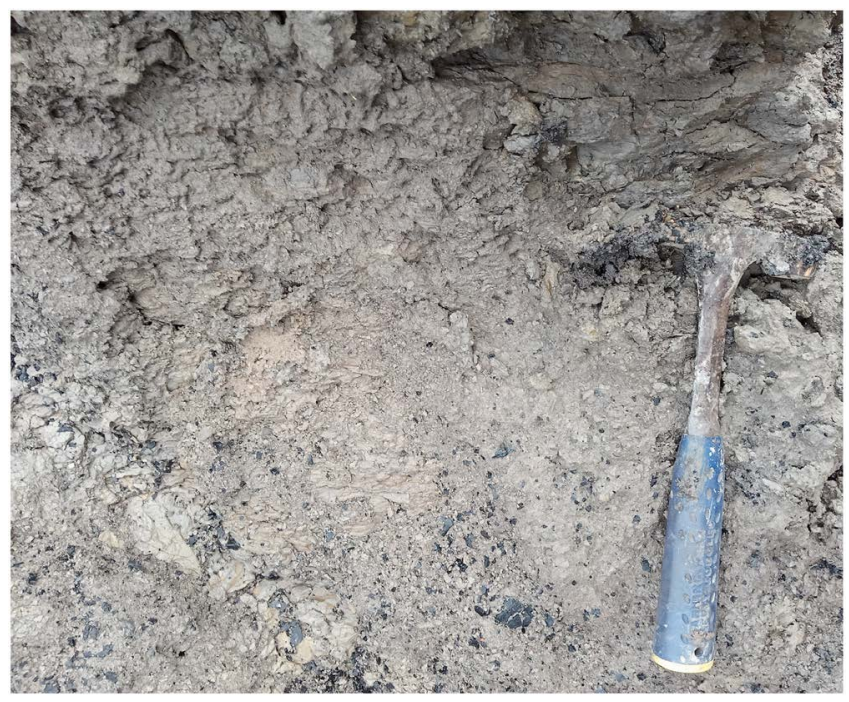

Figure 15. Carbonaceous claystone as roof sedimentary rock seam-D.

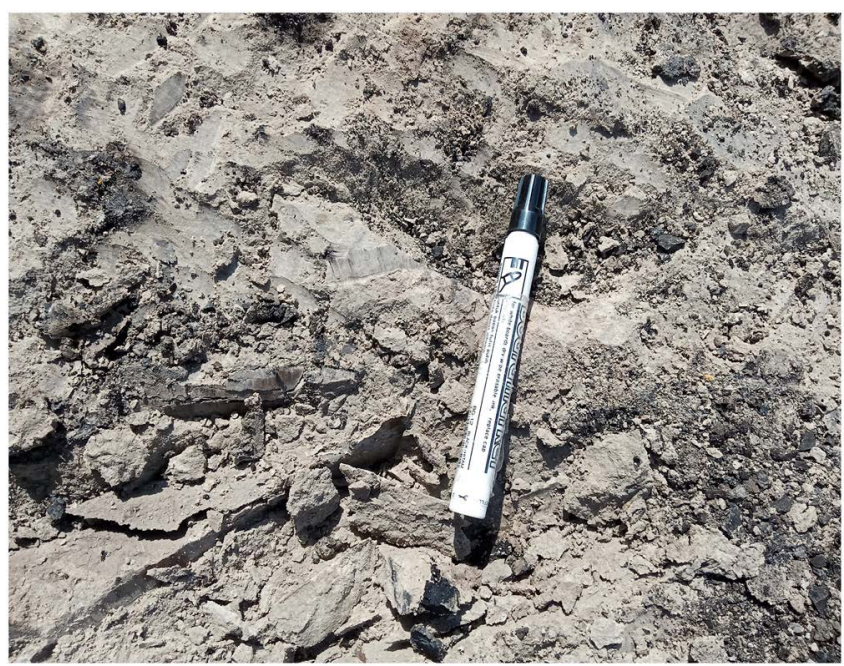

Figure 16. Carbonaceous claystone as roof sediment of seam-E.

which explains the process of forming charcoal, formed because the vegetation/ tree material has burnt before the coalification so that when the bacteria decompose it, the bacteria cannot decompose the coal completely so that it still preserved the charcoal structure. This charcoal is as an entrance for the colloidal silica.

After that, the deposited carbonaceous claystone is releasing silica compounds due to the montmorillonite clay minerals change which react with water to become kaolinite clay minerals by releasing silica $\left(2 \mathrm{SiO}_{2}\right)$ compounds.Silicified coal in the research area occurs due to the leaching process or dissolving the sediment roof layer of coal seam-D with high primary (syngenetic) silica content so that the silica minerals are dissolved by water rain or formation water. Permineralization in wood networks occurs in swamp under acidic conditions. In addition to the floor sediment layer which shows an acidic environment, namely PH 3.4. Based 
on the analysis results, the roof sediment layer also shows acidic PH 4.2 (Sigleo, 1978).

Diessel (1992) explains that bacteria will thrive in environmental conditions that are close to neutral or $\mathrm{PH}$ close to 7. So that coal can decompose properly. In an acidic environment, such as the results of the $\mathrm{PH}$ analysis of seam-D roof and floor sedimentary layer, it shows an acidic $\mathrm{PH}$ so that anaerobic bacteria cannot develop properly, the decomposition process is not optimal so that it still shows the wood structure of the coal.

The wood structure can be a gap in the entry of colloidal silica resulting from the dissolution of carbonaceous claystone which enters through the media of groundwater or formation water supported by the burial pressure and temperature factors (Sigleo, 1978). The silica in the wood structure can replace the structure in coal and it is concentrated to form silicified coal in coal seam-D either in the form of lenses or nodules.

There are two distribution patterns according to (Hidayatullah \& Jati, 2018) silicified coal of seam-D, namely lenses that extend from a few meters to hundreds of meters in length with thickness of $3-5 \mathrm{~cm}$ and nodules with a local pattern with a diameter of $15-80 \mathrm{~cm}$. The pattern of spreading lenses, namely permineralization of silica during and after the process of coalification (syn- and post-coalification mineralization) occurs when the silica solution enters the coal through the gaps in the wood and charcoal structures so that it fills in the coal seams forming elongated lenses. Lenses pattern largely does not reveal the wooden structure. Silicified coal pattern lenses accumulate on the floor of the coal seam " $D$ " because underneath the coal seam " $D$ " is a carbonate claystone which is impermeable or impermeable to silica solution so that the silica is attached to it and forms a long pattern following the openings of the wood structure. Silicified nodule pattern is scattered locally because permineralization of silica occurs both before, during and after the coalification process (pre-, syn-, and post-coalification mineralization) which enters through the cracks of the D-seam wood structure so that the entry process of colloidal silica is only in coal which still shows the wooden structure.

\section{Conclusion and Recommendation}

- The acidity level of coal bearing sediment seam-D which is between 3.4 (roof sediment) - 4.2 (floor sediment) is higher than coal bearing sediment seam-E which has a $\mathrm{pH}$ of 5.4 .

- The result of XRD analysis shows that the seam-D containing silicified coal has clay mineral composition of $47.47 \%$ kaolinite, $21.27 \%$ illite, $23.73 \%$ smectite and $17.54 \%$ mixed layer, while the seam-E which does not contain silicified coal has a composition of kaolinite $35.78 \%$, illite $17.88 \%$, smectite $21.59 \%$ and mixed layer $24.76 \%$.

- The acidity level in coal bearing sediments, especially in roof sediments, is an indication of silica enrichment in clay minerals. The acidity level $(\mathrm{pH})$ and 
silica content in clay minerals, especially in the roof sediments during the deposition, are leached and then dissolves into the cavity of the wood structure in the coal seam to form colloidal silica deposits.

- Kaolinite as clay mineral is believed to be the main source of the formation of silicified coal.

- In order to know in detail of distribution and geometry of silicified coal in the coal seam, it is recommended to perform electrical measurement methods. The purpose of electrical surveys is to determine the subsurface resistivity distribution by making measurements on the ground surface.

\section{Acknowledgements}

The authors thank Ministry of Education and Culture, Republic of Indonesia and Institution of Research and Service Community (LPPM) Universitas Pembangunan Nasional "Veteran" Yogyakarta, Indonesia.

\section{Conflicts of Interest}

The authors declare no conflicts of interest regarding the publication of this paper.

\section{References}

Diessel, C. F. K. (1992). Coal-Bearing Depositional Systems (pp. 5-261). Springer-Verlag. https://www.springer.com/gp/book/9783642756702 https://doi.org/10.1007/978-3-642-75668-9

Hall, R., \& Nichols, G. (2002). Cenozoic Sedimentation and Tectonics in Borneo: Climatic Influences on Orogenesis. Geological Society London Special Publications, 191, 5-22. https://www.researchgate.net/publication/228885862_Cenozoic_sedimentation_and_te ctonics_in_Borneo_Climatic_influences_on_orogenesis https://doi.org/10.1144/GSL.SP.2002.191.01.02

Hidayatullah, R., \& Jati, S. N. (2018). Silicified Coal Dan Implikasinya Terhadap Penambangan Di Daerah Arahan, Kabupaten Lahat, Sumatera Selatan. Jurnal Geomine, 6, 144149.

https://media.neliti.com/media/publications/274065-silicified-coal-dan-implikasinya-te rhada-aa150db2.pdf

https://doi.org/10.33536/jg.v6i3.246

Mencl, V. M., \& Sakala, J. (2009). Silicified Wood from the Czech Part of the Intra Sudetic Basin (Late Pennsylvanian, Bohemian Massif, Czech Republic): Systematics, Silicification and Palaeoenvironment. Neues Jahrbuch für Geologie und Paläontologie, 252, 269288.

https://www.schweizerbart.de/papers/njgpa/detail/252/72831/Silicified_wood_from_th e_Czech_part_of_the_Intra_Sudetic_Basin_Late_Pennsylvanian_Bohemian_Massif_Cz ech_Republic_systematics_silicification_and_palaeoenvironment https://doi.org/10.1127/0077-7749/2009/0252-0269

Satyana, A. H., \& Silitonga, P. D. (1994). Tectonic Reversalin East Baritio Basin, South Kalimantan: Considerationof Types of Inversion Structuresand Petroleum System Significance. 23rd Annual Convention Proceedings, 1, 57-74.

https://doi.org/10.29118/IPA.623.57.74

Sigleo, A. C. (1978). Organic Geochemistry of Silicified Wood, Petrified Forest National 
Park, Arizona. Geochimica et Cosmochimica Acta, 42, 1397-1405.

https://www.sciencedirect.com/science/article/pii/0016703778900455

https://doi.org/10.1016/0016-7037(78)90045-5

Stach, E. (1982). Stach's Textbook of Coal Petrology (3rd ed., pp. 38-47). Schweizerbart Science Publishers. https://www.schweizerbart.de/publications/detail/isbn/3443010180

van Bemmelen, R.W. (1949). General Geology of Indonesia and Adjacent Archipelagoes. In van Bemmelen (Ed.), The Geology of Indonesia. The Haque Martinus Nijhoff.

https://www.worldcat.org/title/geology-of-indonesia/oclc/624477880 